\title{
ALL SHADES OF GREEN: THE CASE OF BOMONTI IN URBAN ISTANBUL
}

\author{
Z. AYGEN \& E. YAGCI \\ Department of Architecture, Mimar Sinan Fine Arts University, Turkey.
}

\begin{abstract}
This article aims to discuss the impact of spatial definitions - as concepts and their implementations - on social and cultural breakdowns/contexts by examining the new genre of green architecture that represents diverse determinations of sustainability. The risk of misinterpretations and reproductions of social and spatial constructions, as well as the terms fashioning the new forms of discriminations justifying destructions, have rarely been given place in philosophical debates. In profound philosophical evaluations, the uses of urban and natural heritage, the terms redefining sustainability, such as 'green', 'smart' and 'eco', are thought to give clues about the political aspects of urban developments. The framework will be based on a critical discussion of these new 'futuristic' terminologies, by re-locating and re-defining them outside the customised power relationships exemplifying the developments in one of the oldest industrial neighbourhoods, Bomonti in the city of Istanbul as a case study.

Keywords: Displacement for the sake of replacement, green economy, (mis)uses of urban and natural heritage, post, smart construction.
\end{abstract}

\section{INTRODUCTION: THE WEARING OF GREEN}

The shamrock, the young sprigs of clover, which became a symbol of Saint Patrick and Ireland, represents in history not only a religious metaphor but also persecution and prosecution of those who wore it. Expressed through the green colour, the shamrock implied the hopes of a fresh and new start. Although it is no more forbidden to wear green in Ireland, cynically still today those in support of the 'green' can be considered by authorities' to be a resistance to law and order. All over the world, demonstrations of the supporters of the 'green' against the extinction of forests, agricultural land and parks can be categorised very easily as rebellion against the government in the power. In 2012, the indigenous people of Ecuador, opposing the open copper-mining concession agreement given to China by their government in the South Amazonian Region, were accused by the President Rafael Correa as an attempt to destabilise his government [1]. Similarly, the protest marchers, opposing the construction of the Villa Tunari-San Ignacio de Moxos Highway through the Isiboro Sêcure National Park, and indigenous territory in Bolivia were called by the President Evo Morales 'enemies of the nation' [2]. Last but not least, there are the recent protests in Turkey evoked by a reconstruction project in Istanbul aiming to cut a considerable number of trees in a public park in order to reconstruct a military building with a shopping mall function (Fig. 1). The protesters in various quarters of the city clapping metal pots and pans together in support of the activists in the park were described by the Prime Minister Erdoğan with the following rhetoric question: 'Are these environmentalists? This is just noise pollution' [3].

The terms 'environmental sustainability' and 'green', often used interchangeably, started to gain more and more importance since the 1970s although the origin of the green building movement can be traced back to the late 19th century and early 20th century. In buildings such as London's Chrystal Palace and Milan's Galleria Vittorio Emanuele II, methods were used that decreased the impact of the new structure on the environment [4]. Ebenezer Howard's Garden City concept with an agricultural belt surrounding the city and regionalism movement from late 1930s onward as a reaction to 


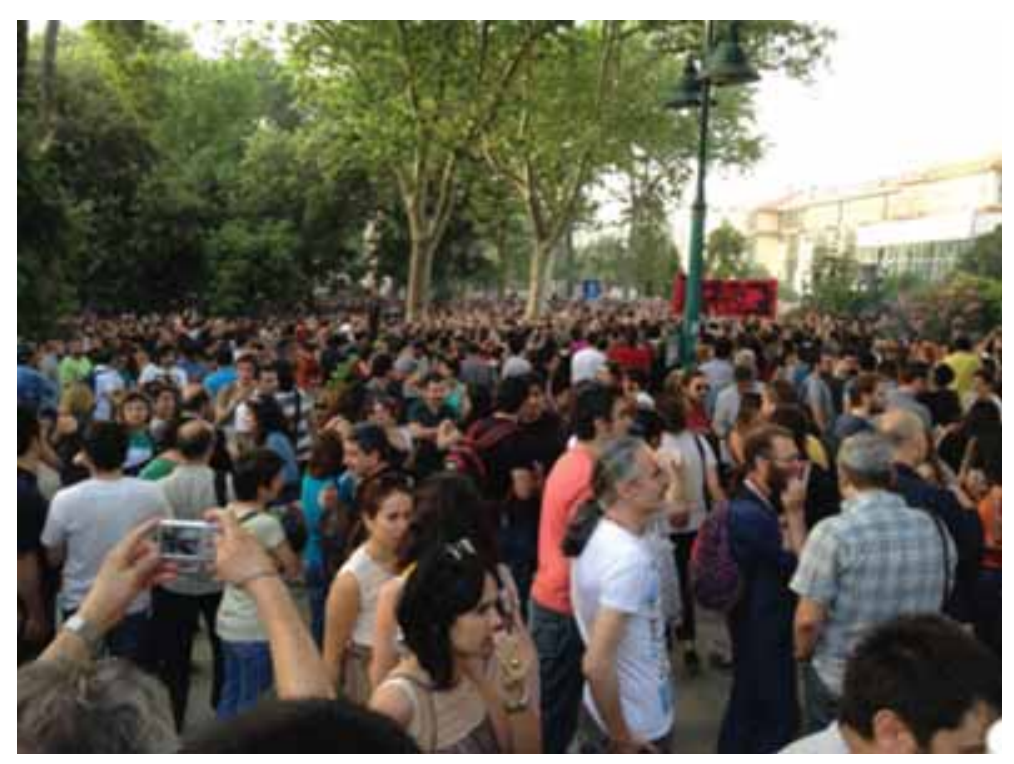

Figure 1: Environmentalists in Gezi Park, Taksim-Istanbul, protesting the reconstruction project of historic barracks by cutting a considerable number of trees in order to build a shopping mall (Image by Eser Yağc1, 13/07/2013).

international modernism could be mentioned as early steps in the environmentalist agenda spite of being not mentioned in most publications within this context. Although most authors [5] refer to the 'Silent Spring' by Rachel Carson in 1962 as the first stone of the green building movement, a much more clearly architectural and urbanism oriented version of it was coined by Lewis Mumford earlier in 1961 as Green Matrix [6]. On the other hand, Austin Green Building Programme in the U.S. claims to have coined the term 'Green Building' [7]. The programme has started with residential buildings, but now it also includes commercial buildings. The word green is now also being used in connection with energy and there is even a 'Shades of Green Energy Radio' [8]. With all these multiple uses, it would be interesting to find out the approximate point where in the timeline of the Green Building Movement, the word 'green' has started to imply to environmental sustainability in reference to the buildings.

In most language groups such as Germanic, Romance, Slavic, Greek, Turkic and Mongolian, the word 'green' is derived from the words for meadow, fresh, sprouting or in leaf. Similarly, for example, in Japanese the descriptive word for green, 'midoru' means to be in leaf or to flourish in reference to trees. It is interesting to note that in some Asian and Polynesian languages, both green and blue are described by the same word, whereas in the Maori culture there are several words describing the green colour. There is a claim developed by comparative linguistics that these terms were coined independently during the evolution of cultural history based on the evidence that there is no joint word describing this colour in Proto-Indo-European languages. However, it is obvious that in most cultures 'green' is associated etymologically with grass, growth and freshness, a fact that explains the religious association of the colour becoming a symbol for emerging religious movements. In addition to the importance of 'green' in early Christianity described in the previous page, colour is also associated with Islam, which is reflected in the national flags of a number of Muslim countries. 
Following the oil crisis and environmental disasters in the 20th century, 'green' was started to be used in a political context and gave its name to political parties probably starting with the 'Die Grünen' in Germany. From that point onwards, 'green' started to become a paradigm in many aspects of life, one of which has been the design paradigm with a futuristic leitmotiv, the reflection of which will be explained in the next chapter.

\section{2 'GREEN' REFLECTIONS OF CONTEXTUAL AMBIGUITY}

Green is not only semantically shaded by different linguistic forms and cultures, but also in its recent global (mainstream) uses refers to sustainability. In its recent meanings, sustainable developments that serve as solutions to environmental problems have turned out to be paradoxical. This paradox could be characterised through conflictive metabolisms of sustainability-embodying dichotomies. In a world, where even the notion of 'green' changes in each culture, a global approach in its application becomes superfluous and misleading. Thus, the semantic intersections within the concept of 'green' require evaluation through possible 'contextual mutations' or 'contexts in flight' [9]. As Latour and Yaneva imply with similar organismic metaphors, fixed contexts for the analysis of concepts of green might disregard actual sustainable approaches, as well as possible solutions at every stage on the development of a project. Nine centuries before Latour, Yaneva and other contemporaries, Ibn Tufail in his Hayy Ibn Yakzan used similar organismic metaphors to emphasise the symbiotic relationship between man and his environment in a naturalist perspective to project his philosophical thoughts [10]. Sami S. Hawi agrees that much earlier than 19th century, scientists and philosophers such as Haeckel, Teilhard de Chardin, in the 12th century Ibn Tufail from Islamic Spain had developed determinist thought, in which the symbiosis of all life forms are in dependence upon one another [11]. Similarly, as early as in the 13th century, Arab scholar Ibn Khaldun had discussed in his famous work The Muqaddimah [12] the ventilation problems in dense cities and their effects on human health. The paradigm of the need for green cities has been introduced to this world much earlier than 20th century, although it is being introduced to today's consumers as a fashionable futuristic concept.

Today, in times of global neo-liberalisation, we witness misinterpretations and misuses of not only the green concept but also of the content and context within capitalism's marriage with fashionised consumerism; to some extent, the word green has derived its label for the sake of the sustainability of this marriage. In such an era, in which neo-liberalism can be considered as the product of the same association, the necessity for distinguishing the actual and the fake becomes more essential. Since consumerist fashion could have only been characterised by its own paradox, its interpenetration with green constructions destroys the integrity of the relations between nature, humanity and culture. These relations had been carried out for ages in philosophic discussions, architectural theories and practices as well as examples of vernacular architecture. The misattribution of fashion for sustainability sometimes even triggers reproductions and reifications of false myths about 'green'. In this aspect, definitions like 'corrupted place', 'slum' and 'deteriorated downtown' might be mis/used to justify fashion and economy-driven projects. They may also manipulate proposed concepts and practices of architectural and urban projects. Misuses of the definitions are apparent in their application to transformations/ageing of the materials, functions, meanings and representations of proposed projects. Thus, the inter-changeability of 'green' and environmentally smart could be seen as one of the most problematic issue for defining the dimensions of green approaches in built environments. As the possibility of misinterpretation inherent in the translation of recent standards, or criteria on green design, the lack of a profound philosophical (ethical) approach to interpret and implement them might cause irreversible results. 
Some of the contemporary theoretical attempts to resolve or characterise the increasing complexity of terms such as 'green' and 'smart', which are considered to have many visible interactions but also some invisible ones, reject to assume these terms as paradoxes. Instead, they seek more holistic approaches by extracting important characteristics of variables within 'heterogeneity of components' to predict their exterior relations with other organic and inorganic forms that make the concepts contextually ambiguous. Anthropologic perspectives by DeLanda [13] upgrading Deleuze's assemblage theory and adapted to an urban theory can be considered as one of the up to date attempts that has the potential to disable reductive approaches. With reference to such philosophical conceptions, the need for anthropologic perspectives relevant to the historical facts and the cultural codes that they bring out becomes important to make conscious analysis and classifications on the uses of 'green'. In this aspect, the transformation of the meanings of green also appeals to culture history for resolving the effects of globalisation and its risks that became more visible in times of rapid changes during the post-war deconstruction

The impact of the world wars on ideas of saving the planet and its natural sources has taken place in the agendas from the 1950s on, beginning as reactions to the crucial destructions. During the post-war western reconstruction, the construction industry gained importance within the growing economies whereby other industrial fabrications started to be decentralised and moved to the new developing countries that are called as 'third world'. The cold war decades between capitalist U.S. and socialist Russia that symbolically ended with the demolishment of Berlin Wall that was accompanied by many movements reclaiming more peace, nature and liberty around the world. Subsequently, sustainability-related constructions such as 'initiations' and NGOs started to emerge along with many other organisations. But the emergence of rating and assessment constructions such as institutions, councils, associations - which brought out diverse definitions and subsequently proceeded to standardise them - coincides with the impact of a new system of national economy-policies and cohesive development policies after the 1980s. The 1990s then, witness the trans-nationalisation of many of these constructions as well as their assessment and rating systems, which turned out to be easily dominated by the capital flows taken up elaborately in David Harvey's [14] text on 'The New Imperialism' as well as in the post-colonial critiques by various authors in the same context. Given these few historical developments, it could be said that globalisation becomes a fact whereby the fashion addict aesthetic culture defeats anthropologic culture and the price of becoming a global city is defined through being dependent to these transnational organisations and their local agencies instead of manifesting a culture-geography friendly green approach. UN-HABITAT-AGFE Reports [15] show that behind the principal causes, the actual causes of forced evictions have been clearing out unwanted social, ethnical, spatial and ecologic entities that are considered to be at margins of the system. In some of these, natural disasters due to climate change are even misused for the justification of displacements as well as social discrimination. The same reports also conceive that the discriminations by legislations and policies have had a similar tendency both in the countries considered as developed and developing countries. Therefore, the myth of third world reproduced by the epistemologies related with these affairs might neglect actual causes regarding right to live, right to the city, right to liveable habitation, by promoting the hygienic shades of green.

Looking into the histories of the new definitions, assessment criteria that are imposed but not adapted to the culture-geographic realities cause confusion. In spite of the contribution of countries to green events and organisations, the institutionalised organisations offering green certificates could be found unreliable by putting high claims on saving the planet and sustaining life on it. For instance in the last two decades, the commitment of the countries to Kyoto Protocol to the United Nations Framework Convention on Climate Change [16] is exposed to pressures of 
the system-driven actor-networks. Those countries that promote the prominent and widespread green certification systems to investors - such as the U.S. based LEED and U.K. based BREEAM are also among the 38 countries with massive industries that are privileged by the Kyoto Protocol, enabling them to exchange their high carbon emissions with developing countries [17].

The inherent cooperation of the green market with finance fosters an environment wherein potential customers get the privilege of investing in the 'greens', facilitated by the generic nature of the green certification systems. The various schemes of this trend are also reminiscent of credit card classes. In BREEAM [18], there are national scheme operators such as the local Green Building Councils that are totally affiliated with BREEAM and bear its titles indiscriminately across regions, whereas LEED [19] system offers to qualified 'greens', certified silver, gold and platinum levels for a wide range of construction types and urban development projects. By contrast, The World Green Building Council (WGBC) [20] has collected more than 97 members as National Green Building Councils of different countries, from Vietnam to Venezuela and including Turkish Green Building Council [21]. The practical knowledge from different culture-geographies are gathered to support and improve the green concepts as an open-source platform under WGBC, despite their support to the mainstream certification systems since its establishment in 2002. Nevertheless, the nongovernmental network of councils and organisations potentially has the flexibility to support broad perspectives regarding green built environments.

In between of design and engineering profession, new technologies accompanied by popular green approaches foster a variety of emerging sub-disciplines both in theory and practice. The increasing popularity of green concerns within the built environment brings out brand-new design approaches such as parametric design, responsive built environments, recyclability or bio-mimicry of materials, green transport, green urbanism, using alternative energy sources, etc. that are accompanied by technological developments. The media coverage, architectural fashions and consumer tendencies might invert the meaning of and intentions behind the idealised concepts that emerge from such developments. In this manner, the circumstances of the design, production and construction of such developments can be exploitive under supposed fair-trade conditions of the green economy mostly dictated by the finance networks. There are numerous problematic trends in the relationship of 'green' to different concepts, contents, contexts and their scales. In this aspect, the factor deciding the scale, and the shade of the green exists also in a dichotomy in which the private green building usually subverts the urban green. The question of massive use of building automation systems to sustain implanted greens, upheld by green certificates, is only a small fragment of this problem. Under these circumstances, the individual's comfort challenges the rights of the majority to live in a comfortable environment.

Within the green building movement, Turkey's tendency to improve green concepts is as recent as that of other countries. The definition of environmental impact assessment and environmental concerns appeared first time in the Environment Law 2872 published in 1983 [22]. In 1993, the Environmental Impact Assessment Legislation (Ç.E.D.) in Turkish Constitution determined the assessors to be governmental institutions and professional chambers. Consequently, with reference to this legislation, many projects that were found to be confrontational with respect to the natural and cultural values were rejected or subjected to court cases and cancelled by the courts. However, in a recently approved legislation, the professional chambers have been excluded from contributing to environmental impact report, thus potentially creating a governmental monopoly on environmental decisions. The regulation 644 from 2011 defined brand-new duties that gave limitless authority to the new Ministry of Urban Developments and Environment while limiting the duties and the autonomy of the chambers [23]. Istanbul, competing with other socially and economically vibrant cities to become more attractive for international investors, is currently under the risk of being destroyed. 
This destructive process is partly green-washed by certifications, an example of which will be presented in the following case study.

\section{CASE STUDY: BOMONTI IN ISTANBUL OR GULLIVER'S VOYAGE TO BROBDINGNAG}

The old residents of Bomonti, a neighbourhood in Istanbul, which takes its name from the Bomonti Beer Factory dating back to 1890 , are currently making Gulliver's journey to Brobdingang, the country of the giants. In the last 10 years, one tall building after another has begun to dominate their skyline, swallowing their already limited green space and putting extra burden on its amenity services, such as water distribution, transport and power supply. The Chamber of Architects Istanbul Branch issued several risk assessment reports with regard to the environmental effects of these buildings and criticised the Implementary Development Plan [24], re-validated for this neighbourhood in 2008, for enabling the construction of tall buildings. In an Environmental Impact Assessment Report dating back to May 2008 [25], the chamber points out that the plan - having no height limitation clauses and encouraging an increase of population in an already densely populated neighbourhood with infrastructure problems - is in contrast with the Construction Zoning Law Nr 3194 from 1985. One of the main issues the report highlights is the fact that 'aiming an ecological balance by building pseudo-natural roof gardens while destroying the actual nature clashes with the principles of architectural profession in regard of future responsibilities'.

Indeed, most of the developers in Bomonti use within their advertisements the word 'green' despite destroying it in order to construct their buildings. For example, Tekfen Bomonti Apartments (Fig. 2), actually one of the few, low-built new constructions built with environmental-friendly materials in the district, is standing partly on the former garden of the Georgian Catholic Church.

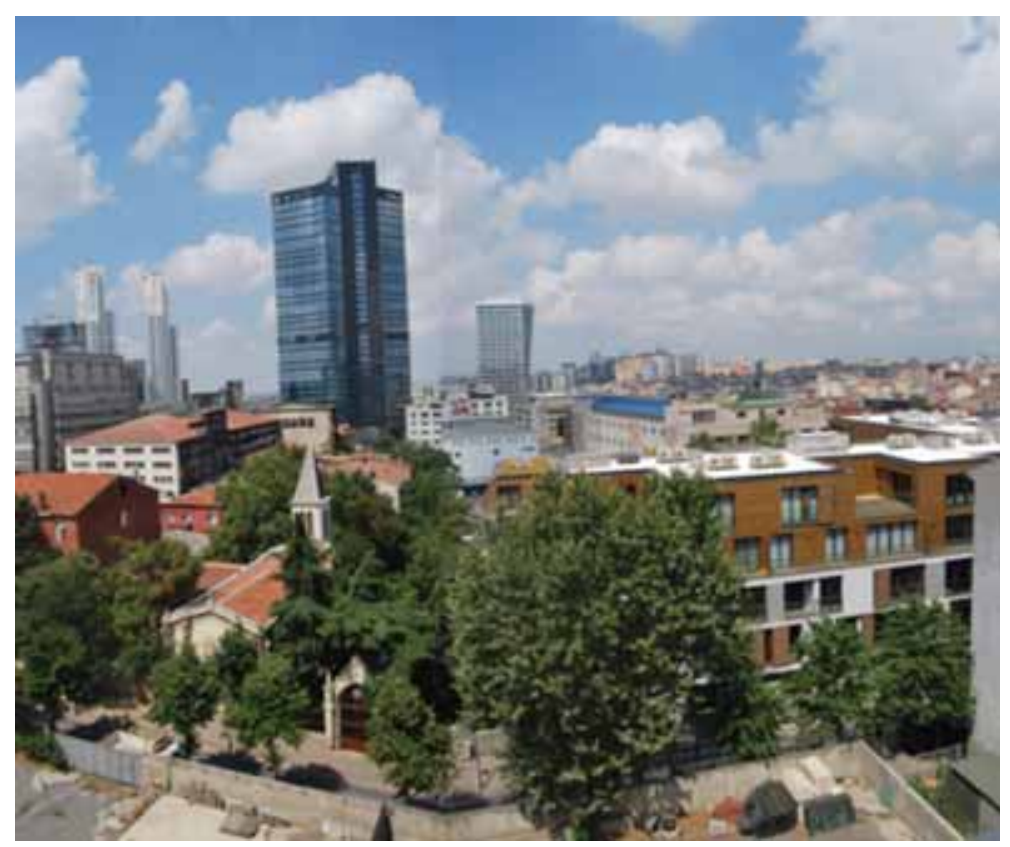

Figure 2: Green architecture built on the green: Tekfen Bomonti Apartments - the tiny square on the left hand of the roof is the referred 'green' (image by Eser Yağc1, 13/07/2013). 
The advertisement of this building includes the phrase that it is 'surrounded with tranquil, green streets' [26]; however, the construction process of the building, which has been awarded with a LEED Gold Certificate [26], includes the cutting of several trees. The tiny roof garden at the top of the building is living proof of the dichotomy mentioned in the above-cited Report by the Chamber of Architects, thus demonstrating the clash between the private and the public.

The valley of Bomonti was once really like most parts of Istanbul at that time. The Bomonti Beer Factory was a brewery in German/Swiss fashion with its own beer garden. The descriptions of this garden include a central pool with a water jet fountain in the middle [27]. There were also other beer gardens, brasseries and cafes surrounding the brewery garden (Fig. 3). Most residents in the rapidly developing neighbourhood named after the brewery were Christians, as Muslims would not work in alcoholic beverage production [28]. As a result, a number of churches belonging to various Christian sects started to be built one after another, especially with the increase in Russian and Georgian immigrants during the First World War, which explains the existence of the above-mentioned Georgian Catholic Church. The clean air and green meadows also attracted orphanages, poor houses and hospitals, most of which still exist despite being dwarfed by tall buildings.

In the first decade following the establishment of the Turkish Republic in 1923, Muslim Turks and Jewish immigrants from various parts of the city also moved into this neighbourhood due to its proximity to the now fashionable Şişli. During that period there was a song praising the privilege of living in Şişli with the refrain 'If you do not own an apartment building in Şişli, you do not live luxuriously' [29]. Unlike the expensive Şişli, Bomonti became the preferred location for the middle class retaining its multi-national and multi-religious character, a feature that is presented today by property developers as 'pioneering innovation in neighbourliness' [30]. At the same time, a very

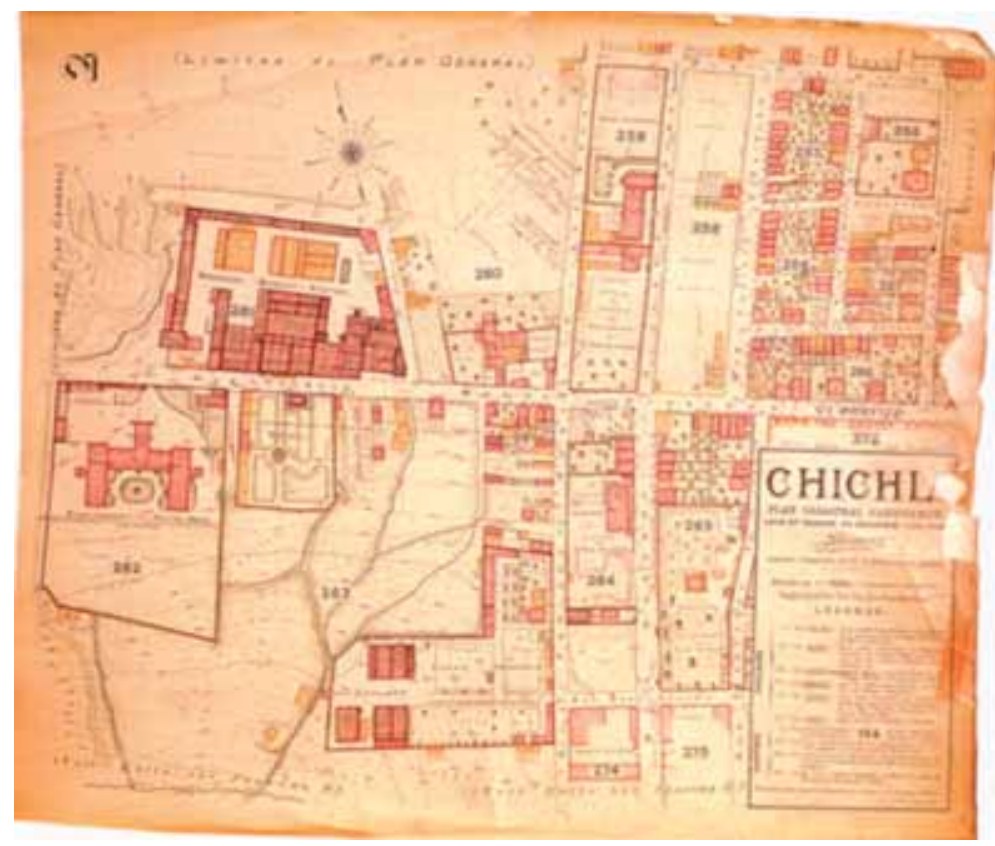

Figure 3: A cadastral map showing Bomonti dating back to the first half of the 20th century; the green structure of Bomonti with brasseries and cafes is clearly visible (Cadastral Insurance Map of Bomonti by Jacques Pervititch from Chamber of Architects Istanbul Branch Archive). 
slow movement towards the settling of light industry has proceeded with the establishment of one textile factory in 1923, followed by two chocolate factories and another textile factory in 1926 [31]. Most of the early factories were owned by the residents of Bomonti due to the advantage of work place and home being close to each other. After 1955, Bomonti was declared officially to be an industrial zone with factories, producing hazardous chemical waste that polluted the residential neighbourhood. This industrialisation was the result of the 1952 Zoning Plan that declared not only Bomonti but also other areas with residential development potential such as the zone between Mecidiyeköy and Levent and the zone between Bomonti and Kağıthane, to be dedicated to the development of industry [32]. The short-sighted decision brought about a disastrous urban mix of light and heavy industry side by side with residential buildings. In addition, squatter areas in green land between the factories and formal residential blocks came to life; as the middle class population in the residential blocks would not work in factories, the factory workers built their own homes near them. In spite of all this, during this period in Bomonti some green areas in the form of urban agricultural hubs had still existed on both sides of the Cevizli River alongside which the Bomonti Beer Factory had been built.

In the last 10 years, Bomonti saw a new development: the residential function cut during 1952 planning decision came back in a completely new form offering residential buildings aimed at both a national and international clientele under the rubric 'smart buildings in a green environment'. Most of these buildings are as tall as possible due to the lack of the height restriction mentioned above; paradoxically, they cause an increase in population in the area but simultaneously a decrease in green and natural amenities. For example, according to the Environmental Impact Assessment Reports by the Chamber of Architects Istanbul Branch, several tall buildings in Bomonti exceed even the highest building coverage ratio $\mathrm{E}=3$ prescribed by the currently valid $1 / 5000$ Master Development Plan and the last 1/1000 Implementary Development Plan dated 08/02/2007. For example, most new buildings in the area have a ratio of $\mathrm{E}=6$, which is double the allowed building coverage ratio [33]. In addition, the Report points out that these buildings benefit from the advantages of the still existing zoning designation of Bomonti as a Central Business District, although they are built mainly for residential purposes. For example, one of these buildings covers an area of 24,000 quadrate meters dedicated to the residential use of 960 persons; however, this project neither invested in any of the necessary infrastructural and social amenities nor took into consideration the given 10 quadrate meters per person, the project should offer a green area of 9600 quadrate meters (Fig. 4). The same project advertises itself as a 'building with terraces enveloped in green' [34] and states having a green area of 1500 square meters, which probably also includes the trees implanted on the terraces.

Similarly, another building with $\mathrm{E}=5$ and also benefiting from the Central Business District zoning regulation, while dedicating an area of 87,400 square meters to residential use for 4000 people [35], received a BREEAM Certificate, as stated in a publication called 'Green Buildings Reference Guide' [36]. The same publication shows that the majority of these buildings with various 'green' certificates have reached this status through certificate agencies, which seems to be a new business sector in support of the construction industry. Most one-bedroom flats in these buildings, the majority of which having no view and offering only bare necessities, are being sold for about 600,000 USD [37]. This is hyper-real in a city where one could buy a historic manor house with four bedrooms in a prime location such as the Bosporus for 685,000 USD [38]. Nejdet Özberk [39] assessed this development as an introduction of new urban utopias created by market forces for those who do not have ample sunshine under the shade of tall buildings. However, factors such as passive ventilation being blocked by massive constructions, changing the wind direction and traffic congestion due to the immense population make this dystopia rather than utopia. It is exactly this dual existence that describes the limits of the green colour scale as part of the contemporary consumerist agenda. 


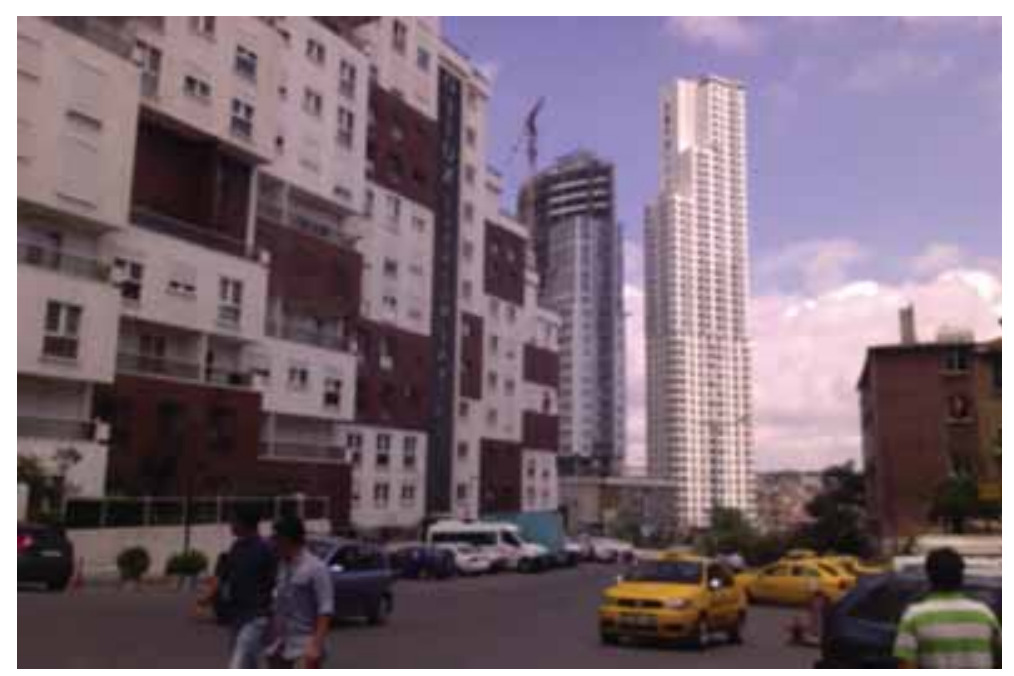

Figure 4: 'A building with terraces enveloped in green!' [35] as advertised (image by EserYağc1, 06/07/2013).

\section{CONCLUSION}

The case study exhibiting various uses of the word 'green', most of the times being used for the description of actually 'non-green' or 'semi-green' items, shows that 'green' has now become a consumer metaphor selling the design paradigm with the futuristic leitmotiv previously discussed in Section 1. As described by Baudrillard [40] it stands now rather as a bio-anthropological postulate representing an essential use value but being presented as a selling point. On the other hand, these shades of green might raise an environmental awareness through the popularising effect of their wide spread impact. As Jameson points out [41] utopias are never real; however, they have the potential to inspire changes within the existing discourse which when idealised risk developing toward a dystopia. When we look into the earliest examples of a new lifestyle utopia incorporating tall buildings, most of them disregard 'green'. For example, while one of the first tall buildings utopias, Erastus Salisbury Field's 'Monument of the American Republic' of 1876, displays a very limited number of roof gardens, Ludwig Hilberseimer's Highrise City (Hochhausstadt) of 1924 is completely devoid of trees [42]. When we look into the development of our case study Bomonti and countless other case studies around the world, it becomes obvious that they all exhibit dystopian landscapes: the last phase of the non-green utopia. On the other hand, a synthesis of fashion and green utopia is starting to lead to a new, green, environmentally responsible practice. If we manage to acknowledge the different equivalents of 'green' in all languages without getting lost in translation, we may for the first time in world history aspire to the actual utopian potential of green. Thus, 'Wearing of Green' can imply again the hopes of fresh and new start.

\section{REFERENCES}

[1] Native Ecuadorans Protest Amazon Mining, Al Jazeera, available at http://www.aljazeera.com/ news/americas/2012/03/20123921342425380.html, 09 March 2012 (accessed 29 June 2013).

[2] Manuela Picq, Evading indigenous consultation in Bolivia. Al Jazeera, available at http:// www.aljazeera.com/indepth/opinion/2011/09/201197105514717750.html, 14 September 2011 (accessed 29 June 2013). 
[3] Hürriyet (Daily Newspaper), p. 116, June 2012.

[4] History of Green Building, available at http://www.marble-institute.com/pdfs/historystoneingreenbuilding.pdf (accessed 29 June 2013).

[5] About the books legacy see, available at http://www.environmentandsociety.org/exhibitions/ silent-spring/overview (accessed 30 June 2013).

[6] Mumford, L., The City in History, Harvest/ HJB: New York, Graphic Section IV, Plate 58,1961.

[7] Austin Eco Network, available at http://www.austineconetwork.com/content/did-you-knowaustin-energy-green-building-program-coined-term-\%E2\% 80\%9Cgreen-building\%E2 $\% 80 \% 9 \mathrm{D}$ (accessed 30 June 2013).

[8] 91.7 FM: available at http://tunein.com/radio/Shades-of-Green-Energy-p260732/ (accessed 11 July 2013).

[9] 'Give me a gun and I will make all buildings move': An ant's view of architecture, available at http://www.bruno-latour.fr/sites/default/files/P-138-BUILDING-VENICEpdf.pdf (accessed28 June 2013).

[10] Ibn Tufail, A.B., The History of HayyIbn Yaqzan, Translated from the Arabic by SIMON OCKLEY, Revised with an Introduction by A.S. Fulton, Frederick A. Stokes company publishers, The Westminster Press: London, W.9 and bound by A. W. Bain \& Co., Ltd, 1929.

[11] Hawi S.S., İslaminatüralistbirdüşünceolarak abiogenesis: Ibntufeyl'ingörüşleri. In Ibntufeylibnsina: HayyIbnYakzan (RuhunUyanışı), translated by: Yusuf Özkan Özburun, Serkan Özburun, Şehabettin Yalçın, Orhan Düz, Derya Örs, Insan Yayinlari, Istanbul, pp. 253-279, 2012.

[12] Ibn-i Haldun, Mukaddime, Translated by: Turan Dursun, Kaynak Yayinlari, İstanbul, Plate 51, pp. 253-255, 2013.

[13] DeLanda, M., A New Philosophy of Society: Assemblage Theory and Social Complexity, Continuum: Hampshire, 2009.

[14] Harvey, D., The New Imperialism, Oxford University Press: New York, 2003.

[15] Forced Evictions: Global Crisis Global Solutions, A Review of the Status of Forced Evictions Globally Through the Work of the Advisory Group on Forced Evictions, Un-Habitat and Other International Actors, available at www.unhabitat.org/pmss/getElectronicVersion. aspx?nr=3187\&alt=1 (accessed May 2013).

[16] United Nations, Framework Convention on Climate Change - Kyoto Protocol, available at http://unfccc.int/kyoto_protocol/items/2830.php (accessed 02 July 2013).

[17] Shiva, V., Karbon Ticareti: Atmosferin Özelleştirilmesi, Kirlilik Süpermarketi Yaratılması, Petrol Değil Toprak: İklim Krizi Döneminde Çevresel Atıklar, Sinek Sekiz Yayınevi, İstanbul, pp. 26-36, 2012.

[18] Green Certified Projects, available at http://www.greenbooklive.com/search/scheme.jsp?id= 241(accessed 05 July 2013).

[19] U.S. Green Building Council (USGBC), available at http://www.usgbc.org/leed (accessed 05 July 2013).

[20] World Green Building Council (WGBC), available at http://www.worldgbc.org (accessed 05 July 2013).

[21] Çevre Dostu Yeșil Binalar Derneği, available at http://www.cedbik.org (accessed 07 July 2013).

[22] Law 2871, available at http://www.ttb.org.tr/mevzuat/?option=com_content\&view=article\& id=49:vre-ka (accessed 10 July 2013).

[23] Law 6223, Regulation No: 644, available at http://www.csb.gov.tr/dosyalar/images/file/644\%20 sayili\%20KHK.pdf.

[24] 1/ 1000 ÖlçekliŞişliDolapdere-PiyalepaşaBulvarlarıveÇevresiUygulamaİmarPlanı, dated 08 February 2007. 
[25] MimarlarOdasi İstanbul BüyükkentŞubesiMeslekiDenetimdeÇevreselEtkiDeğerlendirmesiÇek inceRaporu; Nr. 28. 10. 12075, dated 21 May 2008.

[26] www.bomontiapartmanlari.com/Leed (accessed 05 July 2013).

[27] Çizmeciyan, L.P., İstanbul'da Kayıp Zamanlar, Türkiye İş Bankası: İstanbul, 2010, as cited by Hande Öğüt, Bomonti'den Harbiye’ye, Heyamola: İstanbul, p. 60, 2010.

[28] Aygen, Z., Moscheen, Kirchen und Synagogen in der Türkei, Das Altertum, 45(3), pp. 179-238, 1999.

[29] Lüküs Hayat Operette, Cemal Reşit Rey (Music) \& Ekrem Reşit Rey (Libretto), 1933.

[30] www.bomontiapartmanlari.com (accessed 07 July 2013).

[31] Doldur, H., Bomonti Sanayi Bölgesi’n de Meydana Gelen Değişimler, İ. ÜE debiyat Fakültesi Coğrafya Bölümü, Coğrafya Dergisi, 18, pp. 39-56, İstanbul, 2009.

[32] Aslan, Ş., Birleştirenve Ayrıştıran İşlevleriyle İstanbul'da Boğaz Köprülerinin Toplumsal Dili, İ. ÜSiyasal Bilgiler Fakültesi Dergisi, 44, pp. 107-123, March 2011.

[33] Mimarlar Odası İstanbul Büyükkent Şubesi Mesleki Denetimde Çevresel Etki Değerlendirmesi Çekince Raporu; Nr. 28. 10. 12080, dated 21 May 2008.

[34] http://www.elysiumfantastic.com/ (accessed 07 July 2013).

[35] Mimarlar OdasıIstanbul Büyükkent Şubesi Mesleki Denetimde Çevresel Etki Değerlendirmesi Çekince Raporu, Nr. 28. 10. 11504, dated 18 March 2008.

[36] Yeşil Binalar Rehberi 2013, Supplement to Yirmibir Mimarlık Tasarımve Mekan Dergisi, XXI/ 2013.

[37] www.emlakulisi.com/ant-hill-residence-evlerinde-589-bin-dolardan-besliyor/17958 (accessed 05 July 2013).

[38] http://www.milliyetemlak.com/ilan/arama?kategori=1\&durum=2\&sehir=1\&ilceler=21\&ozell ikler=8-4 (accessed 07July 2013).

[39] Nejdet Özberk, Piyasa Eliyle Üretilen Kentsel Ütopyalar: Özel Konut Şirketlerinin Kentsel Mekan Sипити, available at http://iys.inonu.edu.tr/webpanel/dosyalar/1427/file/NejdetOzberk.pdf (accessed 07July 2013).

[40] Baudrillard, J., Gösterge Ekonomi Politiği Hakkında Bir Eleştiri, translated by Oğuz Adanır \& Ali Bilgin, Boğaziçi Üniversitesi Yayınevi: İstanbul, 2009.

[41] Jameson, F., Ütopya Denen Arzu, Ferit Bural Aydar (transl.). Metis: Istanbul, 2009.

[42] For more information, see: Ruth Eaton, Ideal Cities: Utopianism and the (Un) Built Environment, Thames \& Hudson: London, 2002. 